\title{
Evaluation of Lactate Dehydrogenase Tumor Marker in Children with Gonadal Germ Cell Tumor, Epithelial Tumor, Sex Stromal Tumor, Paragonadal Tumor, and Cyst
}

\author{
Usiwoma-Okeroghene Ataikiru ${ }^{1,2}$ (D) Emil-Radu lacob ${ }^{1,2} \cdot$ Calin-Marius Popoiu $^{1,2} \cdot$ Eugen-Sorin Boia ${ }^{1,2}$
}

Received: 10 March 2021 / Accepted: 17 June 2021 / Published online: 30 July 2021

c) Dr. K C Chaudhuri Foundation 2021

To the Editor: Ovarian and testicular tumors, especially germ cell tumors (GCT), rarely occur in children [1]. Gonadal tumors present with broad symptoms, causing delayed diagnosis in $\geq 70 \%$ of patients and poorer outcomes [2]. Discovering the appropriate tumor marker for detecting and managing cancer patients is essential. Our 5-y (2015-2020) study analyzed the effectiveness of lactate dehydrogenase (LDH), an enzyme [3], in 96 children with cysts, and nonmalignant and malignant (para)gonadal tumors at our hospital, using normal LDH level of $0-300 \mathrm{u} / \mathrm{L}$.

Most patients presented at ages $>12-15$, stage 2, and patient-to-tumor size peaked at $>5-10 \mathrm{~cm}$. Seventy-five out of 96 patients had elevated LDH, 52 being GCT. Sixtyeight out of 96 patients had malignant tumors; of which, 67 patients had LDH -> $300 \mathrm{u} / \mathrm{L}$. The sensitivity, specificity, and area-under-curve values were $98.5 \%, 71.4 \%$, and 0.850 , respectively. The $p$ value was 0.001 .

Ten out of 12 patients with recurrence and $32 / 32$ patients with metastasis had LDH -> $300 \mathrm{u} / \mathrm{L}$. LDH normalized in $59 / 75$ patients between after-the-operation and 6-mo period, and in 12/75 patients after 6 mo. However, LDH remained elevated in 4/75 patients with rhabdomyosarcoma - $767 \mathrm{u} / \mathrm{L}$; dysgerminoma - $2185 \mathrm{u} / \mathrm{L}$ (highest LDH value in our study); mixed GCT $-704 \mathrm{u} / \mathrm{L}$ and $1210 \mathrm{u} / \mathrm{L}$, till they died. The value of LDH for the largest tumor size of $28 \mathrm{~cm}$ was $394 \mathrm{u} / \mathrm{L}$. Eight patients without malignancy, who had 5-26 cm tumor sizes, compressed organs, both gonads affected, torsion or chronic diseases, had LDH -> $300 \mathrm{u} / \mathrm{L}$.

Usiwoma-Okeroghene Ataikiru

usiwomaataikiru@yahoo.com

1 Department of Pediatric Surgery and Orthopedics, University of Medicine and Pharmacy, Victor Babes, Timisoara, Romania

2 Department of Pediatric Surgery and Orthopedics, Louis Turcanu Emergency Children's Clinical Hospital, Timisoara 300011, Romania
The LDH median values were as follows: 251.5 $\mathrm{u} / \mathrm{L}$ - patients without malignancy; $327.0 \mathrm{u} / \mathrm{L}$ - stage $1 ; 432$ $\mathrm{u} / \mathrm{L}$ - stage $2 ; 771.5 \mathrm{u} / \mathrm{L}$ - stage 3 ; and $1210.0 \mathrm{u} / \mathrm{L}$ - stage 4. The $p$ value was 0.031 showing a positive correlation with tumor stage. Considering that stage 3 , the onset of late-stage cancer critical for prognosis [4], fell in the $700 \mathrm{u} / \mathrm{L}$ range, we re-analyzed all patients using LDH - $700 \mathrm{u} / \mathrm{L} ; 24 / 24$ patients with $\mathrm{LDH}->700 \mathrm{u} / \mathrm{L}$ had malignancy. Nineteen out of 21 patients admitted with metastasis; $15 / 16$ patients with elevated LDH level after 6 mo, 23/27 patients at stages $3-4 ; 18 / 28$ patients with poor prognosis; and $4 / 4$ patients who died, all had LDH -> $700 \mathrm{u} / \mathrm{L}$.

\section{Declarations}

Conflict of Interest None.

\section{References}

1. Cecchetto G. Gonadal germ cell tumors in children and adolescents. J Indian Assoc Pediatr Surg. 2014;19:189-94.

2. Doubeni CA, Doubeni AR, Myers AE. Diagnosis and management of ovarian cancer. Am Fam Physician. 2016;93:937-44.

3. Jurisic V, Radenkovic S, Konjevic G. The actual role of LDH as tumor marker, biochemical and clinical aspects. Adv Exp Med Biol. 2015;867:115-24.

4. Dinkelspiel HE, Champer M, Hou J, et al. Long-term mortality among women with epithelial ovarian cancer. Gynecol Oncol. 2015;138:421-8.

Publisher's Note Springer Nature remains neutral with regard to jurisdictional claims in published maps and institutional affiliations. 